\title{
Leisure participation patterns and gender: The survey evidence on Australian adults
}

\author{
A. J. Veal ${ }^{\mathrm{a}}$ \\ School of Leisure, Sport and Tourism, University of Technology, Sydney, NSW, Australia \\ Published in Annals of Leisure Research, 2011, 14(2-3), pp. 120-142.
}

\begin{abstract}
In recognition of the principle that quantitative methods have a role to play in genderrelated studies of leisure, alongside qualitative methods, this paper draws on past and current official Australian national surveys to examine men's time use and leisure participation patterns. Three frequently asserted observations on leisure and gender, and men's leisure behaviour in particular, are addressed. First, the proposition that early survey-based leisure research was 'gender blind' is shown to have not generally been the case in Australia. Second, it is shown that, while it is broadly true that men have more leisure time than women, this is not the case for some key socio-demographic groups. Third, the observation that men have higher levels of participation in leisure activities than women often relies on data on sport and physical recreational activities only; but when a comprehensive definition of leisure is adopted, including such categories as cultural activity and informal outdoor recreation, and when frequency of participation is taken into account, it is found that, while leisure patterns of men are different from those of women, the quantum of participation does not significantly favour men. The paper also addresses the issue of change over time, showing that gender-related patterns of time-use and leisure participation in Australia have changed over recent decades, suggesting that observations based on quantitative empirical data should be reviewed from time to time as new data become available. Finally, the paper examines the life-time distribution of time, revealing a remarkable similarity between men and women.
\end{abstract}

\section{Introduction}

In the late 1970s and early 1980s it was observed that social research on leisure up to that time, especially large-scale leisure participation surveys and research on the work/leisure relationship, had been orientated to men's experiences and had neglected women's experience, or lack of experience, of leisure (Deem 1982; Henderson 1994; Aitchison 2003: 40). The response was the emergence of a substantial program of research focussing specifically on women's leisure experiences, with a major, though not exclusive, emphasis on the use of qualitative methods. However, no similar program of qualitative research was conducted on men's leisure experiences. Furthermore, the interest in the work/leisure relationship waned for a while, but when it did re-emerge in the 1990s it was to focus on the time-squeeze being experienced by the increasing number of women entering the paid workforce while continuing to undertake the bulk of unpaid domestic and childcare work (e.g. Hochschild 1997). With the trend towards more qualitative research in leisure studies

\footnotetext{
${ }^{a}$ For correspondence contact: Tony.Veal@uts.edu.au
} 
generally, the findings of large-scale surveys became less prominent in academic analysis of leisure, although they continued to be conducted by government agencies and to be referred to by way of background in some research reports. As a result it could be argued that, by the 1990s, the situation had reversed and it was research on men's experiences of leisure which had become neglected. Recently, this relative neglect has begun to be addressed, as papers in this special issue of Annals of Leisure Research indicate.

The aim of this paper is to make a modest contribution to redressing the methodological and gender imbalance, focussing on the insights into men's time use and leisure participation patterns which are offered by large-scale Australia national questionnaire-based and time-use surveys. Such surveys, invariably conducted by or on behalf of government departments or agencies for policy purposes, offer a freely available resource which the leisure research community can ill-afford to waste. While qualitative methods have been the favoured primary vehicle for most gender-related research, survey data often plays at least a supporting role (see, for example, Deem 1982: 39; Green et al. 1990; Wearing 1988 16-17, 156; Aitchison 2003: 26). The merits and limitations of qualitative and quantitative/survey methods have been extensively explored in the research literature and it is not proposed to repeat that discussion here. Most commentators conclude that the two types of method are complementary and endorse a ' 'horses for courses' approach (e.g. Talbot 1979: 5; Guba and Lincoln 1998: 195; Henderson 2006: 7; Veal 2003 37). In the case of research on leisure participation and time use, both approaches answer some questions while raising others.

The paper offers challenges or modifications to three frequently asserted observations. First, is the observation that early survey-based research was focussed on males or was 'gender blind': it is shown that, while this may have been the case in some countries, it was not so in Australia. Second, is the observation that men have more leisure time than women: it is shown that, while this is true in general, it is not the case for certain key sociodemographic groups in Australia. Third is the observation that men have higher levels of participation in leisure activities than women: it is shown that this is the case for some categories of leisure in Australia but not for others and does not appear to be the case when frequency of participation is taken into account. The paper also addresses the issue of change over time. Empirical research on leisure typically presents a snap-shot at a particular point in time: one of the potential advantages of surveys repeated at regular intervals over a number of years is that they can throw light on the process of social change, a major concern of social research. This is now possible with some Australian survey data. Finally, the patterns of lifetime time-use distributions are examined and found to be remarkably similar for men and women. Before addressing these issues, the next section discusses large-scale leisure participation and time-use surveys in general.

Arguably, both boys' and girls' leisure has been neglected relative to that of adults but redressing this imbalance is beyond the scope of this paper, since it concentrates on adults. Unless otherwise stated, an adult, in this context, is defined as a person aged 15 and over because this is typical of the lower age-limit used in social surveys in the field.

\section{Large-scale leisure participation and time-use surveys}

Large-scale leisure participation and time-use surveys are conducted, on a regular or one-off basis, at the behest of governments or government agencies in most developed countries, for their own policy-related purposes (Cushman et al. 2006), and are typically designed and conducted by government statistical agencies, such as the Australian Bureau of Statistics, or by contracted commercial polling companies. 
Leisure participation surveys are questionnaire-based and typically conducted by face-toface or telephone interview. Time-use surveys, in addition to a questionnaire, also require respondents to complete a one- or two-day activity diary. Such surveys typically involve a sample of several thousand adults, although some early examples involved samples of just a few hundred. Large samples are required to provide an appropriate level of accuracy for findings related to individual leisure activities and, in some cases, because of the need to analyse data at sub-national level. Details of the main leisure and time-use surveys conducted in Australia are presented in Table 1.

\section{TABLE 1 ABOUT HERE}

A few participation surveys have covered all forms of leisure, but most are limited to particular sectors of leisure of interest to the commissioning agency, such as sport or outdoor recreation or the arts. Because of fragmentation in the relevant ministerial portfolios and related departments in Australian governments, there has been a trend over time towards surveys with increasingly narrow scope. The results from national surveys are also utilised in academic research but researchers must make do with data which official agencies decide to collect and make available in their published reports, although occasionally they are given access to additional tables or the original data files for secondary analysis (for example, see Department of the Arts, Sport, the Environment, Tourism and Territories (DASETT) 1989). Apart from the demanding task of keeping up to date with the changing range of data emanating from a variety of agencies and consolidating results from different surveys with different designs, the nature of the data collected and how it is made available present a number of challenges for the secondary academic user. These include: the definition and scope of leisure and its components, the definition of 'participation'; comparability between surveys within the same series and between different survey series; and availability and coding of socio-demographic variables.

A number of the limitations of traditional, questionnaire-based, participation surveys are to some extent overcome by time-use surveys. They do not, for example, ask respondents to address the concept of 'leisure' or 'free time' but simply to record all forms of activity, however fragmentary, in a diary format over the course of a day. They also enable secondary activities to be recorded in addition to primary activities (for example, doing housework while listening to the radio). Bittman and Matheson (1996: 4) suggest that taking account of secondary activities has a marked effect on the balance of time-use between men and women. Additional questions are also often included. For example, in the 1997 and 2006 Australian Bureau of Statistics (ABS) Australian time-use surveys, a question was asked about respondents' feelings of being pressed for time (ABS 1998: 12, 2008: Tables 20, 21) and in the 1997 survey respondents were asked for whom activities were undertaken (ABS 1998 49). The latter potentially complements the qualitative studies of the subservient role some women play in relation to some men's sport (Dempsey 1989; Thompson 1990) and could possibly offer insights into the pervasiveness of this in sport and the extent to which it operates in other leisure contexts; but unfortunately, the published table for the data is not sub-divided by gender.

Time-use surveys are based on one-day or two-day diaries kept by survey respondents. Diary forms divide the 24 hours into five-minute or 15-minute units and respondents 'block in' individual activities, or 'episodes', thereby indicating start and finish times. In the case of the Australian ABS surveys, for each episode up to seven additional items of information are provided: a description, in the respondent's own words, of the main activity and any simultaneous or secondary activity; the person or group for whom the activity is done; 
location in which the activity takes place; mode of transport for travel episodes; a technology/ communication code (e.g. by telephone, texting, in person); who was with the respondent; and age/health details of household people present (ABS 1998b: 16). Additional household and individual socio-demographic data are also collected using a conventional questionnaire. Given that the average number of episodes recorded is at least 15 per day, it is clear that an enormous amount of complex data is collected for each respondent. Typically, however, the data are reported in highly aggregated form, but the detailed items, for about 7000 individuals in each survey, are available to researchers for re-analysis via the ABS's Random Access Data Library. Dealing with current activities, time-use surveys overcome the problem of possible inaccuracy of recall over extensive periods of time, which arises in participation surveys. It should be noted that the motivation for conducting the main series of time-use surveys in Australian was initiated in the 1980s, not by leisure-related agencies but by the newly formed Office of the Status of Women to examine the extent to which women continued to carry out the bulk of domestic work (ABS 1988: 6).

\section{Early Australian participation and time-use surveys and gender}

In one of the earliest publications on leisure and gender, Rosemary Deem (1986: 8) observed that one of the main approaches of early leisure studies involved the utilization of large-scale surveys and viewed leisure 'as though it were a male or unisex phenomenon'. Although Deem was writing in the British context, similar sentiments have also been expressed by Australian researchers. Thus, Coralie McCormack (1998), in introducing a study involving Australian women and referring in general terms to the beginnings of leisure studies, states: 'Women's leisure was either ignored by male researchers and male dominated funding agencies, or lumped into the "special”, “other" or "problem” group, to be studied only after the 'norms' had been derived from male experience' (1998: 38).

The early experience in Australia in regard to survey evidence on gender-specific patterns of leisure time and activity was, however, very different from that of Britain upon which such discussions of leisure and gender in the literature are typically based. An awareness of gender differences was demonstrated as early as 1962, in a study of leisure in a Melbourne suburban housing estate (item 1 in Table 1), which stated, in the opening paragraph of the chapter on leisure activity: 'Where the wife is working part- or full-time the amount of uncommitted free time available to husband and wife is reduced. The multitude of home duties in villa-type homes is another factor limiting the time available for activities of free personal choice' (Scott and U'Ren 1962: 23). Some, but not all, of the tables in the study report were subdivided by gender and it was noted: 'Twelve per cent of women usually work at domestic tasks on week nights, but only 1\% of men’ (1962: 24).

Gough Whitlam's 1972-75 federal Labor government commissioned three major studies on leisure: 1. a study specifically concerned with women, funded by the Department of Tourism and Recreation and published under the title: Leisure: An Inappropriate Concept for Women? (Anderson 1975) (item 2 in Table 1); 2. the Leisure Activities away from Home survey conducted by the Australian Bureau of Statistics (ABS 1978) as part of the omnibus General Social Survey (item 4); and 3. a study commissioned by the federal Cities Commission, conducted in March 1974 by consultants McNair Anderson Associates and published in 1975 under the title: Australians' Use of Time (Cities Commission 1975) (item 3).

The Anderson study of 800 women in Melbourne, pre-dates studies of leisure and gender in Britain by ten years. It was, by definition, not concerned with men's leisure behaviour, but one table presents information provided by married women survey respondents on the 
frequency with which their husbands went out in the evening unaccompanied by their wives (41\% at least once a week) with the frequency with which they themselves went out unaccompanied by their husbands (19\% at least once a week). This and other findings in this early study indicated the relevance of gender-related power relations in affecting leisure patterns and the relative freedom of men compared with women, factors identified as important in much subsequent research on women's leisure. One of the study interviewers was quoted as observing: 'A great many of the husbands made it difficult for the wives to go out in the evenings. It was not a physical thing but an attitude, and the wife felt very uncomfortable about asking her husband to mind the children' (Anderson 1975: 42). A limitation of the study, which has prevented extensive comparison with later studies, is that it presented information on weekdays and evening activity but not on weekend daytime activity.

The large-scale 1975 ABS survey, with a sample of 18,000 adults, covered a wide range of out-of-home leisure activity and the report contained 22 participation tables, all but two of which were sub-divided by gender. Table 2 is a summary of the basic participation data grouped into seven activity groups and it can be seen that, while men had the highest participation rate in three of the activity groups, comprising sport-related and water-based categories, women had higher participation rates than men in the other four, more social, groups.

\section{TABLE 2 ABOUT HERE}

Despite its substantial sample, comparison with later survey findings has not been possible because of the idiosyncratic format of the basic participation question used: 'In which activities do you spend most of your leisure time away from home? (Include all activities for the last 12 months - that is for any season)'. The undefined qualifier 'most of your leisure time' is similar to the equally imprecise invitation by one of the early British surveys for respondents to identify “the chief things you have done in your leisure time' (Sillitoe 1969: 264). Both question formats appear to be designed to limit the number of activities to manageable proportions, a precaution dropped in later surveys.

The Cities Commission (1975) study was primarily a time-use study and the interest in gender was evident in the title of the main section of the report: 'How male and female wage earners and housewives allocate their time'. Virtually all tables show a breakdown of results between males and females and, in many cases, between 'male wage earners', 'female wage earners' and 'housewives'. None of the 13 sub-sections are concerned exclusively with the leisure experience of men, but two are concerned with full-time housewives who, at that time, represented more than half of women aged 15-64. The statistics on time-use, as shown in Table 3, demonstrate the complexity of the pattern of differences between different gender/occupation groups: male wage-earners had less total (paid and unpaid) work time and more leisure time than female wage-earners, but the differences were just 12 minutes and 18 minutes a day respectively. Non-wage-earning women had the lowest total working hours and the most leisure time.

\section{TABLE 3 ABOUT HERE}

Government-funded survey work on time-use and leisure participation in Australia went into abeyance when the Labor government lost power to the Liberals in 1975 and did not resume until Labor was returned to power in the 1980s. As Table 1 indicates, since that time various survey series have been established. All have presented gender-specific findings.

These early surveys have not been widely referred to in Australian gender-related 
research on leisure, which has tended to be qualitative in nature. Thus, for example, in the eight papers in the 'Women and Leisure' section of the proceedings of an early ANZALS conference (Simpson and Gidlow, 1995), there is only one reference to these early studies: Myra Betschild (1995), in a study of women in mid-life, refers to the Anderson study but only in regard to its title and methodology, not its findings. In Leisure and Feminist Theory, Australian sociologist Betsy Wearing (1998) has much to say on the inadequacies of survey research (1998: 13, 16-17, 188), but makes no reference to the Cities Commission or the 1975 ABS surveys and refers only to the question in the title of the Anderson study, not to its findings (1998: 148).

\section{Time-use and gender in Australia}

As indicated in Table 1, it was not until 1987 that the Cities Commission (1975) study was followed up by the Australian Bureau of Statistics with another Australian time-use survey. This was a pilot survey conducted in Sydney only, but it was followed by a nation-wide survey in 1992, repeated in 1997 and 2006. This section draws on the 2006 survey results.

Comparison of time-use between men and women as a whole hides wide variations related to parental status and relationship with the labour market. Figure 1 compares 2006 weekly time-use patterns for men and women divided into a number of social groups defined by parental and employment status. It draws on spreadsheet results data from the 2006 survey provided on the ABS website (ABS 2008) and on a paper published by the ABS (2009) which presents a level of detail not previously presented in the leisure studies research literature. While 214 activity codes are used by the ABS to record individual activities identified in time-use diaries, published reports tend to group these into just nine categories: 1 . personal care (including sleep); 2. employment related; 3. education; 4. domestic work; 5. child care; 6 . purchasing goods and services; 7 . voluntary work and care; 8 . social and community interaction; and 9. recreation and leisure (ABS 1998b: 16, 30-43). In Figure 1, categories 7 and 8 are combined and labelled 'leisure time' and categories 2-7 are combined and labelled 'total work time', a term also used by Bittman and Matheson (1996: 4) in earlier work on Australian time-use surveys. Both categories include associated travel time. Appendix 1 presents the data upon which the diagram is based, including a breakdown of 'total work time' into its various categories.

\section{FIGURE 1 ABOUT HERE}

Section I of the diagram compares time-use patterns for all men and women aged 15 and over, and confirms the generally accepted view that, on average, men have a lower total work load (56.3 hours a week) than women (57.2 hours). Such overall figures are typical of those referred to in the leisure research literature. But, interestingly, while men's average total work time is one hour less than that of women, their average leisure time (36.1 hours a week) is three hours more than that of women (33.1 hours), the difference being accounted for by less time spent in personal care and sleep.

Much gender-related research has focused on women with dependent children, so Section II of the diagram provides data on parents of children aged under 15 in two-parent families who comprise about $19 \%$ of the adult population. These are divided into four sub-groups depending on paid work status, namely:

A. both parents in full-time paid employment (4.1\% of the adult population);

B. one parent employed full-time and one part-time (7.5\%);

C. one parent in paid employment and the other not (6.5\%); and 
D. neither parent in paid employment (0.9\%).

In the two cases (groups B and C) which comprise almost three quarters of two-parent families, fathers have a larger weekly total work load than mothers. However, their leisure time is the same (group B) or greater (group C) than that of the mothers in those groups. Thus, when domestic and employment conditions are taken into account the conventional view that men invariably have more leisure time than women because they have a lower total work load, is found to be not always the case. In general, fatherhood is accompanied by an average reduction in men's leisure time of about 10 hours a week, but Appendix 1 indicates that this is not the result of increased unpaid, domestic or childcare work, but a significant increase in paid work. Thus, rather than a sharing, 'symmetrical family' (Young and Willmott 1973), pattern, this appears to reflect an enhancement of the traditional male 'provider' role.

Part II of the diagram includes lone parents of children aged under 15 ( $2 \%$ of adults). The data published by ABS do not include a gender break-down for sole parents, but other data indicate that about $90 \%$ of this group are women, so sample data for men would be unreliable and the information presented relates almost entirely to women.

Part III concerns full-time students aged 15-24, who constitute 9\% of the 15+ population. Despite males and females having almost identical total work-loads, the males have 4.6 hours a week more leisure time, again due to the smaller amount of time spent in personal care and sleep.

Part IV and V of the diagram concerns people aged 65 and over and other non-parent adults aged under 65 , which between them account for $68 \%$ of the adult population. Here the disparity between men and women is clear, with men having between three and four hours less total work and between two and three hours more leisure time than women. Curiously, these are larger differences than in the main three two-parent family groups (A-C). Thus, it would seem that parenthood, which has been the focus of much gender-related leisure research to date, is associated with greater equality between men and women in work and leisure time rather than less.

It was noted above, that taking account of secondary activity, performed simultaneously with primary activities - for example, listening to the radio while doing housework - can have a marked effect on the picture presented of gender-related patterns of time use. It is not possible to pursue this topic in detail in this paper, but Figure 2 shows the effects for all men and women. It shows that men engage in 26.3 hours of secondary activity a week, while women engage in 36.6 hours. In both cases the bulk of this is leisure activity (19.6 hours for men and 22.6 for women), but for women, a substantial proportion is work activity (12.0 hours). The result is that combined leisure time is equal, at 55.7 hours for both men and women, while the difference between women's and men's total working hours increases from one hour a week to almost eight.

\section{FIGURE 2 ABOUT HERE}

The published ABS time-use survey reports present a breakdown of leisure time into a number of leisure activity types and a summary for 2006 is presented in Table 4. It can be seen that the three hours a week of additional leisure which men enjoy compared with women is more than accounted for by four hours more spent watching television and other audio/ visual media, which will tend to be home-based.

\section{TABLE 4 ABOUT HERE}


One of the activities, which is often said to characterise men's leisure patterns, is that they are sport spectators. Table 4 indicates that the average amount of time spent watching sport live (i.e. not on television) is only 0.23 hours, or 14 minutes, a week. While Table 5 , below, indicates that just over half of adult males watch sport live at least once in the course of a year, the relatively low time figure is reflected in the ABS survey finding that more than half of adult males who watch live sport, do so only once or twice a year (ABS 2007a: 21).

\section{Participation in leisure activities}

In gender-related research, it is desirable to adopt an inclusive definition of leisure, since men and women differ not only in the amount and quality of available leisure time, but also in the range of activities undertaken. Failure to do this can result in the presentation of incomplete or distorted views of leisure participation patterns. However, it has been common, in those gender-related leisure research discussions which make reference to survey data, to base comparisons exclusively, or mainly, on sport participation, in which men have higher participation rates than women, ignoring activities such as informal outdoor recreation or the arts, in which, survey sources indicate, men have lower participation rates than women (Aitchison 2003: 103; Shaw and Henderson 2005; Green et al. 1990: 58-60; Wearing 1998: 18, 29-30, 155-57).

While some early Australian participation surveys covered all aspects of leisure, in the last couple of decades, different surveys have been conducted for different leisure sectors for different government department/agency clients. In seeking to present a comprehensive picture, Table 5 therefore includes data from a number of the sources listed in Table 1 . It presents comparisons between men's and women's participation rates for six groups of activity: I exercise, recreation and sport; II live sport spectating (i.e. not on television); III cultural activities; IV visiting pubs and clubs; V outdoor recreation activities in natural areas (such as national parks); and VI visiting urban parks. Home-based activity is not included since it is not included in any of the recent surveys, although a proportion of some forms of exercise, recreation and sport (e.g. keep fit activities) takes place in the home. However, timeuse surveys, as discussed above, do include home-based activity.

\section{TABLE 5 ABOUT HERE}

The Exercise, Recreation and Sport Survey (ERASS, see Table 1 item 8) covers almost 170 activities, but published data include only the 55 most popular, with participation rates of $0.1 \%$ and above and Table 5 includes the 31 activities in which men, women or both have a participation rate of $1 \%$ or more. 'Participation' means engaging in an activity at least once in the year prior to interview. This is far from being a wholly satisfactory measure of participation, for a variety of reasons (see Cushman et al. 2006), but it is the main measure used in official reports, and the one measure which can be used to compare data from different surveys, as is done here. The overall participation rate, which refers to participation at least once in the past year in at least one of the 170 activities covered, shows men with a participation rate of $79.6 \%$, which is only $0.5 \%$ more than women's participation rate of $79.1 \%$. There is also only a small difference in the average number of different activities engaged in during a year, which is 1.6 for men and 1.4 for women. Despite these small differences, the pattern of differences in participation levels in many individual activities is marked. Men have a higher participation rate in 20 of the 31 activities, the levels are equal in one activity (martial arts) and women have a higher participation rate in 10, including three of the top four activities, walking, aerobics/fitness and swimming. 
Of the other five activity groups in Table 5, it can be seen that only in sport spectating and visiting pubs and licensed clubs are men dominant. Women have higher rates of participation in all nine cultural activities, while in natural area recreation activities and urban park visiting, the differences are too small to be statistically significant.

Section VII of Table 5 shows the average number of activities per person and it can be seen that there is virtually no difference between the figure for men, 8.35, and that for women, 8.27.

The limited nature of the one-year participation rate is mentioned above. Other measures of participation are available, but are often not included in the published reports of the surveys. Two such measures are available in relation to the Exercise, Recreation and Sport Survey (ERASS) and are discussed below.

An obvious enhancement of the one-year percentage participation rate would be to include frequency, so that participation in an activity once only in the course of the year would count as 1 , while participation once every week would count as 52 . This 'volume of activity' measure could then be aggregated for the total of the activities engaged in by an individual. It is, of course, a more useful measure for providers of leisure facilities, since it equates to annual visits. Access to the data file has enabled this secondary analysis to be carried out for ERASS 2007, but has not been possible for other surveys. Figure 3 seeks to replicate, approximately, the groups used in Figure 1, for volume of ERAS activity rather than time-use.

\section{FIGURE 3 ABOUT HERE}

It can be seen that, using this measure, for adults as a whole and for all except two of the social groups, women engage in a greater volume of ERAS activity than men. Parenthood does not appear to result in men's participation levels increasing at the expense of those of women; indeed, the two groups in which men engage in more activity than women are young people in high school and people aged 65 and over.

Official guidelines suggest that for significant health benefits to be obtained, exercise should take place for at least 30 minutes on most days, that is, on four or more days a week, with total weekly duration of at least two hours. Table 6 presents data from the 2007 ERASS for frequency of recent (i.e. the two weeks prior to interview) participation in physical exercise and indicates that, with regard to frequency, 29\% of men meet the health guidelines, while $32 \%$ of women do so. With regard the duration guidelines, $46 \%$ of men and $45 \%$ of women meet the guidelines, a difference which is not statistically significant.

\section{TABLE 6 ABOUT HERE}

The conclusion to be drawn in relation to activity-based data is therefore similar to that drawn above in relation to leisure time availability. When the data are examined in more detail than simple male and female averages, the traditional view, in this case that men engage in more leisure activities than women, is found to be an over-simplification. In particular, when cultural activities and informal outdoor recreation are included and frequency of participation is taken into account, it can be seen that, while leisure patterns of men are different from those of women, the quantum of participation does not significantly favour men.

\section{Change over time}


This section of the paper addresses the issue of social change and the proposition that, in the social sciences, conclusions drawn from data at one point in time may not apply at other times. Studying change over time on the basis of leisure participation patterns is difficult because of the sensitivity of survey responses to changes in the wording of questions and other changes to the design of the survey process and the tendency for official agencies to indulge in such changes for a variety of reasons (Veal 2003). Time-use surveys avoid this problem to some extent, because of the discipline of 24 hours in a day, which even government agencies cannot alter! But changes in coding of activities between surveys can cause problems. But even when surveys are comparable, challenges remain to take account of long-term ambient social changes, such as the trend towards higher levels of education, and cyclical change, such as the level of unemployment, which can affect average time use and leisure participation patterns.

In regard to time use in Australia, Michael Bittman (1991a, 1998) has undertaken analysis of the ABS 1992 time-use surveys data and compared them to data from the 1974 Cities Commission time-use survey and 1987 ABS pilot time-use survey, weighted to reflect the Australian population as a whole. ${ }^{i}$ Figure 4 presents Bittman's comparisons for these surveys and the 1987 and 1992 ABS time-use surveys, with the 1997 and 2006 ABS time-use survey data added.

\section{FIGURE 4 ABOUT HERE}

In the 1974-87 period, men had more leisure time and more work time than women. In the period 1987-97 men's work time declined and leisure time increased, but both these trends went into reverse between 1997 and 2006. In this latter period, for both men and women, working time increased and leisure time fell. This is consistent with a falling unemployment rate during this period, which results in a larger proportion of the population being in work, so increasing overall average working hours for the whole population. But this was clearly not the only factor at work, since unemployment actually peaked in the early 1990s. The 2006 situation described above, with men having one hour a week less total work than women, but three hours a week more leisure, appears to have been in place since the late 1990s.

In addition to examining trends in availability of leisure time, trends in the pattern of use of such time are also of interest. Figure 5 shows the changes in time spent on leisure activity categories for Australian men between 1997 and 2006. We have already seen that leisure time for men fell by two hours per week in this period, but what is remarkable about the data in Figure 5 is that, despite this, television viewing increased in the period by almost two hours. This means that time spent on all other leisure activities fell by four hours. Of particular note, and concern, from a public policy point of view, is the fall of 1.2 hours, or 30 per cent, in the time allocated to sport and outdoor activity. The reasons for this would require more detailed research, but increased fatigue and inability to commit to regular involvement in activities due to longer working hours could explain a shift to more physically passive leisure patterns.

\section{FIGURE 5 ABOUT HERE}

\section{Life time}


As demonstrated above, at different times of their lives people have different patterns of time use. In addition, different people have different life courses, in terms of periods which are devoted primarily to education, paid work, parenthood and retirement. Thus overall patterns and totals of work and leisure will vary, individually and in terms of group averages. This can be illustrated by diagrammatic representations of the life course (see Ruthven 1983 and Veal 1987: 12-15 for earlier Australian and UK examples respectively). Figures 6 and 7 show examples of a life pattern for an Australian man and woman respectively, based on current life-cycle-specific time-use patterns. Life time, from age 6 to 80, in the case of the male, and to 85 in the case of the female, is divided into 5-year periods along the horizontal axis, with full-time education extending to the age of 20, followed by periods of full-time and part-time employment, no paid employment, parenthood and retirement. There are 1825 days in a 5year period and this is depicted on the vertical axis with 2006 data on patterns of work and leisure for these life-cycle periods drawn from Appendix 1. The two scenarios are indicative but, of course, wholly artificial, since they are based on a snap-shot picture of behaviour patterns in 2006 - but by the time any current 6-year-old has reached the age of 80 the world would have changed significantly. Even using 2006 data, a variety of patterns for the horizontal axis could, of course, be selected.

\section{FIGURES 6 AND 7 ABOUT HERE}

The remarkable feature of these diagrams is their similarity. For both men and women $22 \%$ of life time is devoted to leisure and, while the balance of paid and unpaid work is different, the total work commitment is the same for both, at $27 \%$, while the other two time-use categories vary by $1 \%$ only. The totals are, of course, affected by the additional five years of lifeexpectancy for women. Much of the discussion and comparison of work, leisure and gender is, however, focussed on the pre-retirement stage of life so, in addition to the whole post-5years-old life span, Table 7 presents the data for the period 16-65, which is approximately the definition often used for 'working-age' population. The effect of omitting the retirement years is similar for men and women: it increases the proportion of work time and reduces the proportion of leisure time, for both.

\section{TABLE 7 ABOUT HERE}

\section{Concluding comments}

A number of conclusions can be drawn from the above analysis. First, official large-scale surveys of time-use and leisure participation patterns conducted in Australia have, unlike the experience in some countries, addressed gender issues from the beginning (in the 1970s) and continue to offer insights alongside qualitative research. Second, examination of recent Australian time-use data shows that, while the traditional picture of men enjoying more leisure time and less total (paid and unpaid) work time than women is generally borne out, this is not true for all groups when parental and employment status are taken into account. Furthermore, fatherhood typically results in significant increases in total work-time and significant reductions in leisure time for men. Third, both men and women in Australia experienced an increase in total work time and a reduction in leisure time over the decade 1997-2006, one feature of this change being a reduction of $30 \%$ in the time spent by males in sporting activity. Fourth, when considering participation in individual leisure activities it is found that, while men have higher levels of participation in sport and physical activities, 
when cultural participation and informal outdoor recreation are taken into account, there is a less dramatic overall difference in participation levels between men and women. Furthermore, when frequency of participation is taken into account, men are shown to have a lower volume of activity of exercise, recreation and sport activities than women. Fifth, when the life span from the age of six years to 80/85 is considered, the distribution of time between total work and leisure is remarkably similar for men and women.

\section{References}

Aitchison, C.C. 2003. Gender and leisure: Social and cultural perspectives. London: Routledge.

Anderson, R. 1975. Leisure - an inappropriate concept for women? Canberra: AGPS.

Australian Bureau of Statistics (ABS). 1978. General Social Survey: Leisure Activities Away from Home, May 1975. (Cat. No. 4104.0). Canberra: ABS.

Australian Bureau of Statistics (ABS). 1988. Time Use Pilot Study, Sydney, May-June, 1987. (Cat. No. 4111.1), Canberra: ABS.

Australian Bureau of Statistics (ABS). 1994. How Australians Use Their Time, 1992, (Cat. No. 4153.0). Canberra: ABS.

Australian Bureau of Statistics (ABS). 1998a. How Australians Use Their Time, 1997, (Cat. No. 4153.0). Canberra: ABS.

Australian Bureau of Statistics (ABS). 1998b. Time Use Survey, Australia: Users' Guide, (Cat. No. 4150.0). Canberra: ABS.

Australian Bureau of Statistics (ABS). 1999. Sports Attendance Australia, 1999. (Cat. No. 4174.0), Canberra: ABS.

Australian Bureau of Statistics (ABS). 2003. Sports Attendance Australia, 2002. (Cat. No. 4174.0), Canberra: ABS.

Australian Bureau of Statistics (ABS). 2007a. Sports Attendance Australia, 2005-06. (Cat. No. 4174.0), Canberra: ABS.

Australian Bureau of Statistics (ABS). 2007b. Attendance at Selected Cultural Venues and Events, Australia, 2006, (Cat. No. 4114.0). Canberra: ABS.

Australian Bureau of Statistics (ABS). 2008. How Australians Use Their Time, 2006, (Cat. No. 41530DO001. Canberra, ABS, available online only at: www.abs.gov.au.

Australian Bureau of Statistics (ABS). 2009. Work, life and family balance. Australian Social Trends, September, (Cat. No. 4102.0), Canberra: ABS, available online only, at: www.abs.gov.au.

Betschild, M. 1995; Towards a theory of leisure and pleasure? New perspectives on women's lived experience of midlife. In Leisure Connexions: Proceedings of the Australian and New Zealand Association for Leisure Studies Second Conference, ed. C. Simpson and B. Gidlow, 97-101. Christchurch, NZ, Dept of Parks, Recreation and Tourism, Lincoln University.

Bittman, M. 1991a. Juggling time: How Australian families use time: A report on the secondary analysis of the 1987 pilot survey of time use, prepared for the office of the status of women, Department of Prime Minister and Cabinet, May 1991. Canberra: AGPS.

Bittman, M. 1991b. Home-centred leisure: a trap for women. In Women and Leisure:

Towards 2000: Proceedings of a Symposium, University of Newcastle, 11-12 July, ed.

P. Brown, 28-36. Newcastle, NSW: University of Newcastle.

Bittman, M. 1998. The land of the lost weekend? Trends in free time among working age 
Australians, 1974-1992. Loisir et Société 21,no. 2: 353-78.

Bittman, M., and G. Matheson. 1996. “All Else Confusion”: What Time Use Surveys Show About Changes in Gender Equity. SPRC Discussion Paper No. 72, Sydney: Social Policy Research Centre, University of New South Wales, available at: www.sprc.unsw.edu.au/ media/File/dp072.pdf.

Cities Commission. 1975. Australians' use of time. Melbourne: Cities Commission.

Cushman, G., A.J. Veal, and J. Zuzanek. 2006. National leisure participation surveys: a future. In Free time and leisure participation: International perspectives, ed. G. Cushman, A. J. Veal and J. Zuzanek, 283-92.Wallingford, UK, CABI Publishing.

Deem, R. 1986. All work and no play? The sociology of women and leisure. Milton Keynes, UK, Open University Press.

Deem, R. 1982, Women, leisure and inequality. Leisure Studies 1, no. 1: 29-46.

Dempsey, K. 1989. Women's leisure, men's leisure: A study in subordination and exploitation. Australian and New Zealand Journal of Sociology 25, no. 1: 27-45.

Department of the Arts, Sport, the Environment, Tourism and Territories (DASETT). 1989. Ideas for Australian recreation: Commentaries on the recreation participation surveys. Canberra: AGPS.

Department of the Arts, Sport, the Environment, Tourism and Territories (DASETT). 1991. Recreation participation survey: February 1991. Canberra: DASETT.

Green, E., S. Hebron, , and D. Woodward. 1990. Women's leisure? What leisure? Basingstoke, UK: Macmillan.

Guba, E.G., \& Lincoln, Y.S. 1998. Competing paradigms in qualitative research. In The landscape of qualitative research: Theories and issues, ed. N.K. Denzin and Y.S. Lincoln 195-220.Thousand Oaks, CA: Sage.

Henderson, K.A. 1994. Broadening an understanding of women, gender and leisure. Journal of Leisure Research 26, no. 1: 1-7.

Henderson, K.A. 2006. Dimensions of choice: A qualitative approach to recreation, parks, and leisure research, $2^{\text {nd }}$ ed.. State College, PA: Venture.

Hochschild, A.R. 1997. The time bind. New York: Metropolitan Books.

McCormack, C. 1998. Memories bridge the gap between theory and practice in women's research. Annals of Leisure Research 1, 37-50.

Parks and Wildlife Group, NSW Department of Environment, Climate Change and Water. 2010. Nature-based Outdoor Recreation Demand and Preferences-Quantitative Research Findings: Greater Sydney. Prepared by Ipsos-Eureka. Sydney; Parks and wildlife Group, NSWDECCW, available at: www.environment.nsw.gov.au/research/ demandforoutdoorrecreation.htm.

Ruthven, P. 1983. Future economic and social environments. In National Leisure Seminar: Discussion Papers, ed. National Leisure Seminar Steering Committee, 101-30. Melbourne: Victorian Government Printing Office.

Scott, D., and R. U'Ren. 1962. Leisure: A social enquiry into leisure activities and needs in an Australian housing estate. Melbourne: F.W. Cheshire.

Shaw, S.M., and K. Henderson. 2005. Gender analysis and leisure constraints: an uneasy alliance. In Constraints to Leisure, ed. E.L. Jackson, 23-34. State College, PA Venture.

Sillitoe, K.K. 1969. Planning for leisure. London: HMSO.

Simpson, C., and B. Gidlow., ed. 1995. Leisure connexions: Proceedings of the Australian and New Zealand Association for Leisure Studies second conference. Christchurch, NZ, Dept of Parks, Recreation and Tourism, Lincoln University.

Standing Committee on Recreation and Sport. 2008. Participation in Exercise, Recreation 
and Sport 2007. Canberra, Australian Sports Commission, available at: www.ausport. gov.au/info/statistics.htm.

Sydney Parks Group. 2007. Sydneysiders’ Use of Parks, 2007. Sydney, SPG, summary available at: http://sydneyparksgroup.net.au/.

Talbot, M. 1979. Women and leisure: A state of the art review for the Sports Council-SSRC Joint Panel on Sport and Leisure Research. London: Sports Council.

Thompson, S.M. 1990. "Thank the ladies for the plates”: The incorporation of women into sport. Leisure Studies 9, no. 2: 121-35.

Veal, A. J. 1987. Leisure and the future. London: Allen and Unwin

Veal, A.J. 2003. Tracking change: leisure participation and policy in Australia, 1985-2002. Annals of Leisure Research 6, no. 3: 246-78.

Wearing, B. 1998. Leisure and feminist theory. London: Sage.

Wimbush, E., and M. Talbot. ed. 1988. Relative freedoms: Women and leisure. Milton Keynes, UK: Open University Press.

Young, M., and P. Willmott. 1973. The symmetrical family. London: Routledge and Kegan Paul. 
Table 1. Australian leisure and time use surveys NB: Need to find out if tables refs are ok as they are

\begin{tabular}{|c|c|c|c|c|c|c|c|c|c|c|}
\hline & First & Freq. & Latest & Focus & Agency & Survey & Age-range & $\mathrm{N}$ & Area & Reference \\
\hline \multicolumn{11}{|c|}{ Early surveys } \\
\hline 1 & 1961 & One-off & & $\begin{array}{l}\text { Neighbourhood } \\
\text { leisure }\end{array}$ & $\begin{array}{l}\text { Brotherhood of St } \\
\text { Lawrence }\end{array}$ & Leisure: a Social Enquiry ... & $21+$ & 178 & Fitzroy, Vic. & $\begin{array}{l}\text { Scott and U'Rren } \\
\text { (1962) }\end{array}$ \\
\hline 2 & 1974 & One-off & & Women's leisure & $\begin{array}{l}\text { YWCA + Dept Tourism } \\
\text { \& Recreation funding }\end{array}$ & $\begin{array}{l}\text { Leisure - an Inappropriate } \\
\text { Concept for Women? }\end{array}$ & $\begin{array}{l}\text { Mothers } \\
16-45\end{array}$ & 834 & Melbourne & Anderson (1975) \\
\hline 3 & 1974 & One-off & & Leisure time & Cities Commission & Australians' Use of Time & 18-65 & 1492 & $\begin{array}{l}\text { Melbourne \& } \\
\text { Albury-Wodonga }\end{array}$ & $\begin{array}{l}\text { Cities Commission } \\
\text { (1975) }\end{array}$ \\
\hline 4 & 1975 & One-off & & $\begin{array}{l}\text { Leisure activities - } \\
\text { out of home }\end{array}$ & $\mathrm{ABS}^{* *}$ & $\begin{array}{l}\text { Leisure Activities Away } \\
\text { from Home }\end{array}$ & $15+$ & 18,000 & National & ABS (1978) \\
\hline 5 & 1985 & 2/year & 1991 & All leisure & DASETT*** & National Recreation Survey & $14+$ & 2000 & National & DASETT (1991) \\
\hline 6 & 1987 & One-off & & Time-use & ABS & Pilot time-use survey & $15+$ & $1611 \S$ & National & ABS (1988) \\
\hline \multicolumn{11}{|c|}{ Contemporary surveys } \\
\hline 7 & 1992 & $\begin{array}{l}5-10 \\
\text { yrs }\end{array}$ & 2006 & Time-use & ABS & Australians’ Use of Time & $15+$ & c. 7000 & National & $\begin{array}{l}\text { ABS }(1994,1998 a, \\
2008,2009)\end{array}$ \\
\hline 8 & 2001 & Annual & 2009 & $\begin{array}{l}\text { Exercise, recreation } \\
\text { and sport }\end{array}$ & $\begin{array}{l}\text { Standing Committee on } \\
\text { Recreation \& Sport }\end{array}$ & $\begin{array}{l}\text { Exercise, Recreation and } \\
\text { Sport Survey }\end{array}$ & $15+$ & 13,000 & National & SCORS (2008) \\
\hline 9 & & 5 yrs & 2006 & Sport spectating & ABS & Sports Attendance & $15+$ & 25,000 & National & ABS $(1999,2003,07)$ \\
\hline 10 & & 5 yrs & 2006 & $\begin{array}{l}\text { Cultural venues and } \\
\text { events }\end{array}$ & & $\begin{array}{l}\text { Attendance at Cultural } \\
\text { Venues and Events }\end{array}$ & $15+$ & 14,000 & National & ABS (2007?a or b?) \\
\hline 11 & 1998 & 3 yrs & 2007 & Parks & Sydney Parks Group & $\begin{array}{l}\text { Sydneysiders' Use of Parks } \\
\text { survey }\end{array}$ & $16+$ & 1500 & Greater Sydney & $\begin{array}{l}\text { Sydney Parks Group } \\
\text { (2007) }\end{array}$ \\
\hline 12 & 2009 & One-off & & $\begin{array}{l}\text { Nature-based } \\
\text { recreation }\end{array}$ & $\begin{array}{l}\text { Parks and Wildlife } \\
\text { Group, NSW DECCW }\end{array}$ & $\begin{array}{l}\text { Nature-based outdoor } \\
\text { recreation demand }\end{array}$ & $18-75$ & $\begin{array}{l}2800 \\
\text { (NSW) }\end{array}$ & Greater Sydney & $\begin{array}{l}\text { Parks and Wildlife } \\
\text { Group etc. (2010) }\end{array}$ \\
\hline
\end{tabular}

* 2008, 2009 data also now available. § 3181 diary days. ** ABS: Australian Bureau of Statistics *** Dept of the Arts, Sport, the Environment, Tourism and Territories 
Table 2. Participation in leisure activities, Australian adults (15+), 1975

\begin{tabular}{lcc}
\hline Activities* & Males & Females \\
\hline & $\%$ & $\%$ \\
Attending entertainment & 34.0 & $\mathbf{3 9 . 4}$ \\
Socialising & 61.8 & $\mathbf{6 8 . 2}$ \\
Water activities & $\mathbf{3 7 . 5}$ & 26.4 \\
Organisation meetings & 16.6 & $\mathbf{2 1 . 8}$ \\
Sport - participating & $\mathbf{3 5 . 8}$ & 22.2 \\
Sport - spectating & $\mathbf{2 6 . 7}$ & 17.8 \\
Other general recreation & 46.8 & $\mathbf{5 0 . 0}$ \\
None & 7.9 & 8.0 \\
\hline
\end{tabular}

Source: ABS (1975) see Table 1 item $4 .{ }^{*}$ Activities 'in which you spend most of your leisure time away from home ... for the last 12 months'.

Table 3. Time-use, men and women aged 18-69, Melbourne, 1974

\begin{tabular}{lccc}
\hline & $\begin{array}{c}\text { Wage-earning } \\
\text { women }\end{array}$ & $\begin{array}{c}\text { Non-wage-earning } \\
\text { women }\end{array}$ & $\begin{array}{c}\text { Wage-earning } \\
\text { men }\end{array}$ \\
\hline Total personal care/sleep & $\mathbf{1 0 . 5}$ & $\mathbf{1 1 . 1}$ & $\mathbf{9 . 9}$ \\
\hline Work time & & & 7.2 \\
Paid work & 4.8 & 0.0 & 0.8 \\
Housework & 2.9 & 4.9 & 0.2 \\
Childcare & 0.4 & 1.5 & 0.4 \\
Shopping & 0.7 & 0.9 & $\mathbf{8 . 6}$ \\
Total work time & $\mathbf{8 . 8}$ & $\mathbf{7 . 3}$ & 1.8 \\
Free time* activity & & & 0.5 \\
TV-watching & 1.1 & 1.9 & 0.8 \\
Social/entertainment & 0.4 & 0.2 & 0.4 \\
Being with friends & 0.9 & 0.9 & 0.0 \\
Active leisure & 0.5 & 0.7 & 0.4 \\
Civic \& collective & 0.1 & 0.2 & 0.5 \\
Reading & 0.4 & 0.5 & 0.6 \\
Free time travel & 0.5 & 0.4 & $\mathbf{5 . 0}$ \\
Other free time & 0.8 & 0.8 & $\mathbf{2 4 . 0}$ \\
Total free time* activity & $\mathbf{4 . 7}$ & $\mathbf{5 . 5}$ & $\mathbf{2 4 . 0}$ \\
Total hours & $\mathbf{2 4 . 0}$ &
\end{tabular}

Source: Cities Commission - see Table 1 item 3, Appendix 3 and Table 10, p. 15-Melbourne sample only-weekday and weekend data combined to produce an average. *free-time is the term used in the ?? 
Table 4. Leisure time-use patterns by gender, Australian adults(15+), 2006

Males Females

Hours per week

\begin{tabular}{lrr}
\hline TV/audio/visual media & 18.4 & 14.4 \\
Sport and outdoor activity & 2.7 & 1.9 \\
Talking*/ correspondence & 2.8 & 4.2 \\
Reading & 2.5 & 2.9 \\
Games, hobbies, arts, crafts & 1.1 & 1.3 \\
Socialising/entertainment/cultural & 1.5 & 1.8 \\
Religious/community & 1.2 & 1.8 \\
Attendance at sports events & 0.2 & 0.1 \\
Associated travel & 2.0 & 2.1 \\
Other & 3.7 & 2.8 \\
Total & 36.1 & 33.1 \\
\hline * including on the telephone. Source: ABS data - see Table 1, item 7.
\end{tabular}


Table 5. Participation in leisure activities by gender, Australian adults (15+)

\begin{tabular}{|c|c|c|c|c|c|}
\hline \multirow[t]{2}{*}{ Activity } & \multicolumn{2}{|c|}{ Male Female } & \multirow[t]{2}{*}{ Activity } & \multirow{2}{*}{$\begin{array}{r}\text { Male } \\
\% *\end{array}$} & \multirow{2}{*}{$\begin{array}{r}\text { Female } \\
\%^{*}\end{array}$} \\
\hline & \%* & $\% *$ & & & \\
\hline \multicolumn{3}{|c|}{$\begin{array}{l}\text { I Exercise, recreation and sport, } 2007 \text { (1) } \\
\end{array}$} & II Sport spectating (live), 2006 (3) & 51.9 & 36.9 \\
\hline Walking (2) & 24.1 & 41.6 & III Cultural activities (4) & & \\
\hline Aerobics/fitness & 15.2 & 25.1 & Cinema & 62.5 & 67.7 \\
\hline Cycling & 13.1 & 6.5 & Public library & 26.7 & 41.2 \\
\hline Swimming & 11.1 & 12.9 & Museum & 21.7 & 23.4 \\
\hline Running & 9.6 & 5.8 & Pop music concert & 24.8 & 25.6 \\
\hline Golf & 9.1 & 2.2 & Art gallery & 19.9 & 25.4 \\
\hline Soccer (outdoor) & 6.6 & 1.8 & Opera/Musical theatre & 12.0 & 20.6 \\
\hline Tennis & 6.6 & 5.0 & Theatre & 13.1 & 20.8 \\
\hline Bushwalking & 5.1 & 6.2 & Dance performance & 6.9 & 13.3 \\
\hline Cricket (outdoor) & 4.7 & 0.4 & Classical music concert & 8.2 & 10.6 \\
\hline Basketball & 4.1 & 2.1 & At least one cultural activity & 82.4 & 87.1 \\
\hline Australian rules & 3.5 & 0.3 & No. of cultural activities/person & 2.1 & 2.7 \\
\hline Surf sports & 3.2 & 0.6 & IV Pubs/clubs, 1991 (5) & & \\
\hline Touch football & 3.1 & 1.5 & Pubs & 28.2 & 17.5 \\
\hline Fishing & 2.9 & 0.4 & Licensed clubs & 21.4 & 15.0 \\
\hline Soccer (indoor) & 2.6 & 0.5 & \multicolumn{3}{|c|}{ V Natural area recreation, Sydney, 2009 (6) } \\
\hline Weight training & 2.6 & 1.6 & Picknicking $\perp$ & 86.2 & 87.9 \\
\hline Rugby league & 2.1 & 0.1 & Sightseeing $\perp$ & 78.3 & 79.9 \\
\hline Motor sports & 2.0 & 0.2 & Scenic driving $\perp$ & 69.0 & 67.8 \\
\hline Martial arts & 1.9 & 1.9 & Water sports $\perp$ & 65.3 & 64.5 \\
\hline Lawn bowls & 1.8 & 1.1 & 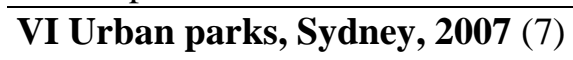 & & \\
\hline Squash / racquetball & 1.7 & 0.6 & Visited in last year $\perp$ & 95.6 & 95.5 \\
\hline Rugby union & 1.6 & 0.0 & Visited in last week (spring) $\perp$ & 51.8 & 49.0 \\
\hline Cricket (indoor) & 1.5 & 0.1 & VII No. of activities/person (8) & 8.87 & 8.75 \\
\hline Canoeing/kayaking & 1.1 & 0.8 & & & \\
\hline Ice / snow sports & 1.1 & 0.6 & & & \\
\hline Yoga & 0.8 & 4.7 & & & \\
\hline Netball & 0.7 & 5.6 & & & \\
\hline Dancing & 0.6 & 3.0 & & & \\
\hline Horse riding etc. & 0.6 & 1.4 & & & \\
\hline Aquarobics & 0.2 & 1.7 & & & \\
\hline At least one sport etc. activity & 79.6 & 79.1 & & & \\
\hline No. of activities per person & 1.6 & 1.4 & & & \\
\hline
\end{tabular}

$\perp$ Due to sample size, differences between men and women in sections V and VI not statistically significant at the 0.05 probability level all other \% differences are significant.

* \% participating in last year except pubs/clubs (last month).

(1) Activities with at least $1 \%$ participation by men or women or both. Source: see Table 1, item 8.

(2) Not bushwalking or competitive walking.

(3) Source: see Table 1 item 7; (4) Source: see Table 1 item 9.

(5) Source: see Table 1 item 5, NB 1991 data (the latest available for this activity group). Visiting in last (summer) month.

(6) Source: see Table 1 item 12. Data relate to Greater Sydney. Male/female \%s calculated from Table 4.2.1, p. 21.

(7) Source: see Table 1 item 11. Data relate to Greater Sydney. Age-range 18-75.

(8) Avge no. of activities/person is the aggregate of all above individual participation rates, except the last, which double counts part of the previous item, 'Visited in last year'. 
Table 6. Frequency of participation in physical activity by Gender, Australian adults (15+), 2007

\begin{tabular}{lcc}
\hline $\begin{array}{l}\text { Sessions/week in last } \\
\text { two weeks }\end{array}$ & $\begin{array}{c}\text { Males } \\
\%\end{array}$ & $\begin{array}{c}\text { Females } \\
\%\end{array}$ \\
\hline 4 or more & 28.7 & 31.9 \\
$2-3$ & 18.4 & 17.9 \\
Less than 2 & 19.5 & 16.8 \\
None & 33.4 & 33.4 \\
Total & 100.0 & 100.0 \\
\hline More than 2 hrs & 46.1 & 45.4 \\
\hline
\end{tabular}

Source: ERASS - see Table 1, item 8.

Table 7. Life-time activity patterns, Australians

\begin{tabular}{|c|c|c|c|c|}
\hline & \multicolumn{2}{|c|}{$\begin{array}{c}\text { 'Working age' life time } \\
\text { (aged 16-65) }\end{array}$} & \multicolumn{2}{|c|}{$\begin{array}{c}\text { Total post-5 life time } \\
\text { (aged 6-80/85) }\end{array}$} \\
\hline & Male & Female & Male & Female \\
\hline & \multicolumn{4}{|c|}{$\%$ of time } \\
\hline Sleep/personal care & 43.8 & 44.0 & 45.7 & 45.9 \\
\hline Education/voluntary & 4.7 & 5.0 & 5.8 & 5.3 \\
\hline Unpaid work & 14.3 & 21.6 & 12.8 & 19.3 \\
\hline Paid work & 19.4 & 11.8 & 13.3 & 7.4 \\
\hline Total work & 38.4 & 38.4 & 31.9 & 32.0 \\
\hline Leisure & 17.8 & 17.6 & 22.4 & 22.1 \\
\hline Total & 100.0 & 100.0 & 100.0 & 100.0 \\
\hline
\end{tabular}

Source: ABS data - see Table 1 item 7, based on 2006 data 
Appendix 1. Time-use by social group, Australian adults, 15+, 2006

\begin{tabular}{|c|c|c|c|c|c|c|c|c|}
\hline & $\begin{array}{c}\text { Personal } \\
\text { care/sleep }\end{array}$ & $\begin{array}{l}\text { Education } \\
+ \text { voluntary }\end{array}$ & $\begin{array}{l}\text { Paid work- } \\
\text { related* }\end{array}$ & $\begin{array}{l}\text { Unpaid } \\
\text { work }\end{array}$ & $\begin{array}{l}\text { Total } \\
\text { work }\end{array}$ & Leisure & Total & $\begin{array}{l}\text { Popn, } \\
\text { millions }\end{array}$ \\
\hline & \multicolumn{8}{|c|}{ Hours per week } \\
\hline \multicolumn{9}{|c|}{ I. Total population aged $15+$} \\
\hline Men & 75.6 & 6.1 & 31.9 & 18.3 & 56.3 & 36.1 & 168 & 7.90 \\
\hline Women & 77.7 & 6.9 & $9 \quad 16.5$ & 33.8 & 57.2 & 33.1 & 168 & 8.20 \\
\hline \multicolumn{9}{|c|}{ II. Couples with children aged under 15 living at home } \\
\hline \multicolumn{9}{|c|}{ A. Both parents employed F/T } \\
\hline Fathers & 70.7 & 4.4 & 53.1 & 17.7 & 75.2 & 22.1 & 168.0 & 0.33 \\
\hline Mothers & 70.7 & 8.8 & 33.2 & 35.4 & 77.4 & 19.9 & 168.0 & 0.33 \\
\hline \multicolumn{9}{|c|}{ B. One parent employed F/T, one P/T } \\
\hline Fathers & 69.6 & 5.5 & 50.8 & 17.7 & 74.1 & 24.3 & 168.0 & 0.60 \\
\hline Mothers & 70.7 & 8.8 & 19.9 & 44.2 & 72.9 & 24.3 & 168.0 & 0.60 \\
\hline \multicolumn{9}{|c|}{ C. One parent employed, one not employed } \\
\hline Fathers & 70.7 & 6.6 & 46.4 & 17.7 & 70.7 & 26.5 & 168.0 & 0.52 \\
\hline Mothers & 74.1 & 8.8 & 3.3 & 57.5 & 69.6 & 24.3 & 168.0 & 0.52 \\
\hline \multicolumn{9}{|c|}{ D. Neither parent employed } \\
\hline Fathers & 81.8 & 8.8 & 8.8 & 28.7 & 46.4 & 39.8 & 168.0 & 0.07 \\
\hline Mothers & 79.6 & 11.1 & 4.4 & 46.4 & 61.9 & 26.5 & 168.0 & 0.07 \\
\hline \multicolumn{9}{|l|}{ III. Lone parents** } \\
\hline Employed F/T & 65.3 & 9.3 & 43.6 & 28.0 & 80.9 & 21.8 & 168.0 & 0.10 \\
\hline Employed P/T & 72.6 & 10.6 & 18.2 & 39.4 & 68.1 & 27.2 & 168.0 & 0.11 \\
\hline Not employed & 85.5 & 12.2 & 0.0 & 42.8 & 55.0 & 27.5 & 168.0 & 0.15 \\
\hline \multicolumn{9}{|c|}{ IV. Full-time students, aged 15-24 } \\
\hline Men & 78.3 & 33.2 & 8.4 & 7.4 & 49.0 & 40.7 & 168.0 & 0.70 \\
\hline Women & 82.8 & 27.7 & 7.2 & 14.2 & 49.1 & 36.1 & 168.0 & 0.79 \\
\hline \multicolumn{9}{|c|}{ V. Other non-parents ${ }^{* * *}$} \\
\hline Men & 74.9 & 2.2 & 37.0 & 18.2 & 57.4 & 35.6 & 168.0 & 4.52 \\
\hline Women & 73.9 & 4.3 & 23.7 & 33.1 & 61.1 & 33.0 & 168.0 & 3.91 \\
\hline \multicolumn{9}{|l|}{ VI. People aged 65+ } \\
\hline Men & 82.8 & 5.4 & 5.5 & 25.2 & 36.1 & 49.1 & 168.0 & 1.17 \\
\hline Women & 82.0 & 1.6 & 0.9 & 37.0 & 39.5 & 46.5 & 168.0 & 1.36 \\
\hline
\end{tabular}

* Work-related includes travel to work and, for the unemployed: job search time.

** No gender split available, *** Aged 15-65, non-parents, not F/T students.

Source: ABS data See Table 1, item 7. Couples data derived from ABS (2009) Figures 
Appendix 2. Exercise, recreation and sport participation, Australian adults, 15+, 2007

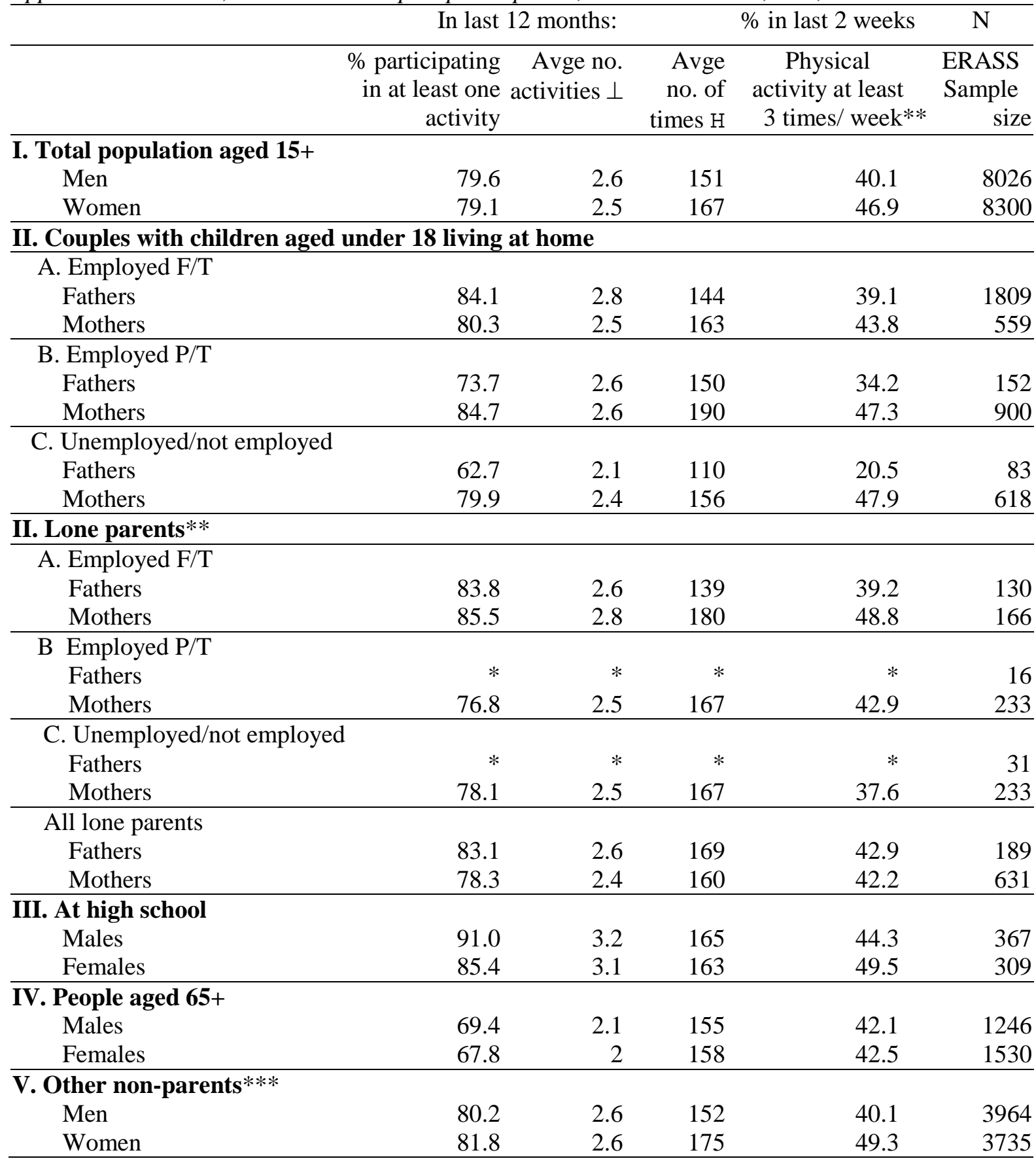

* Sample too small for reliability. ** = minimum for health benefits.*** Aged 15-65, non-parents, not high school students. $\perp$ averaged across all members of the group, not just participants.

Source: ERASS: see Table 1, item 8. Secondary analysis undertaken at UTS: data file supplied by SCORS. 
Figure 1. Time-use by social group, Australian adults, 15+, 2006

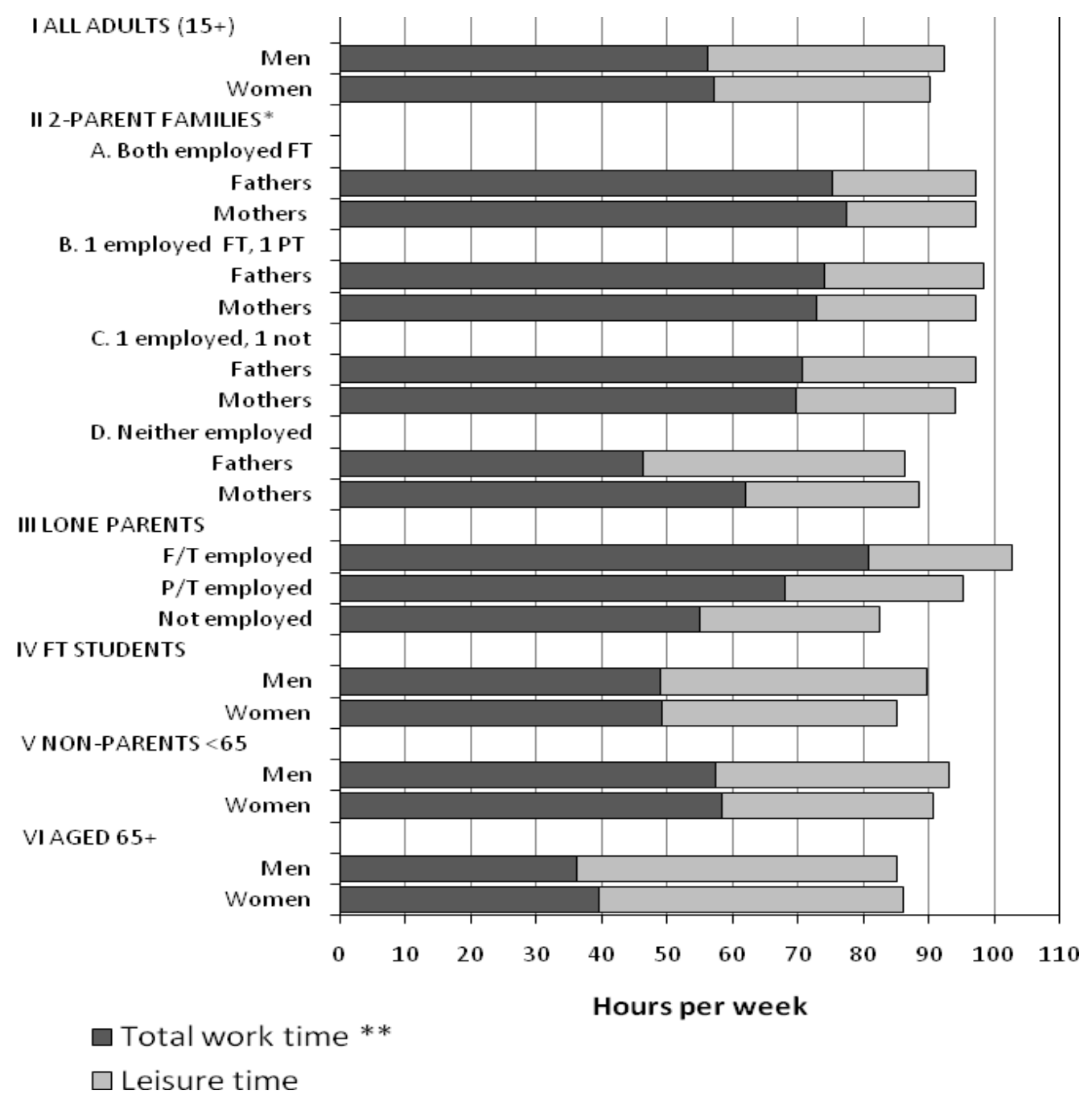

Source: Based on ABS time-use survey data (see Table 1, item 7)

$*$ two-parent families with children aged under 15 at home. $* *$ Total work time $=$ paid work + domestic work + child care + voluntary work/care + education; Total work time + leisure time + personal/sleep time $=168$ hours per week $($ for breakdown see Appendix 1). 
Figure 2. Primary and secondary activity by gender, Australian adults (15+), 2006

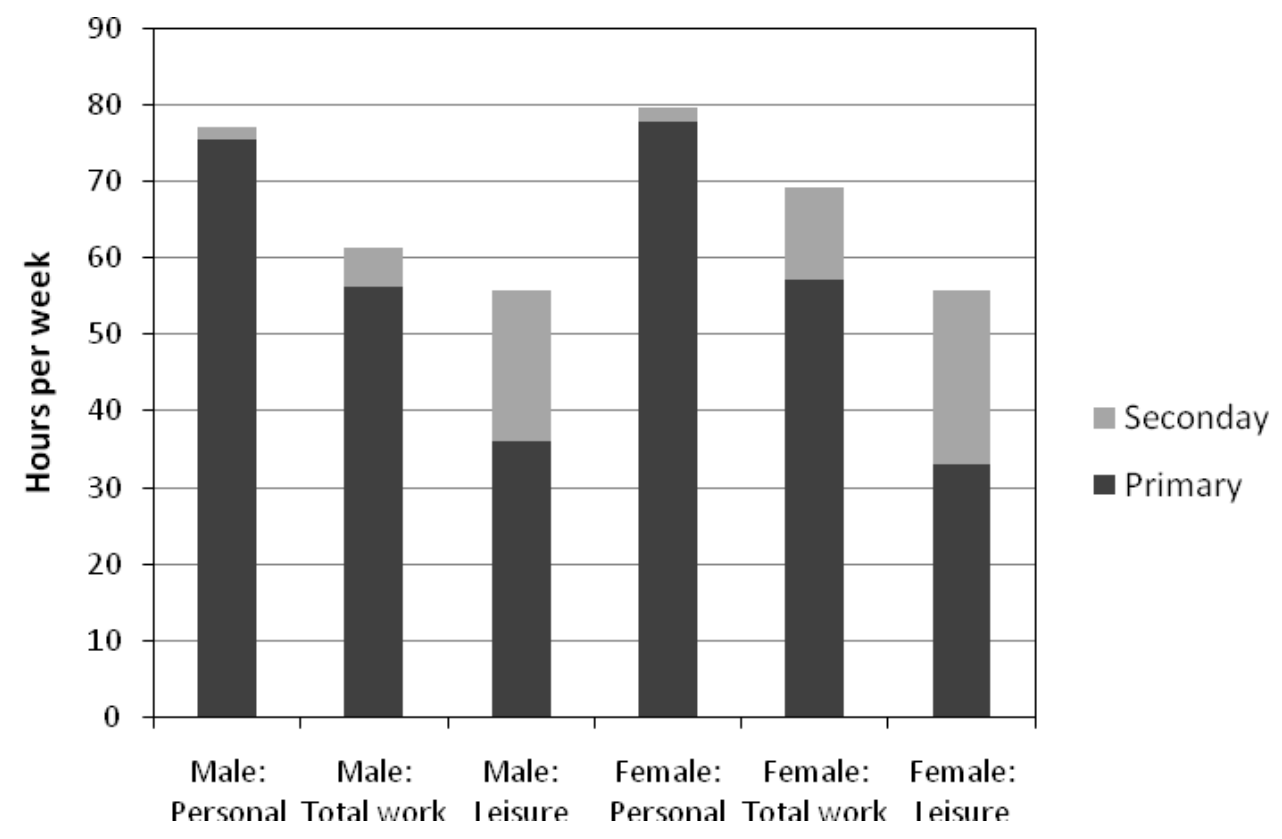


Figure 3. Volume of exercise, recreation and sport participation, Australian adults (15+), 2007

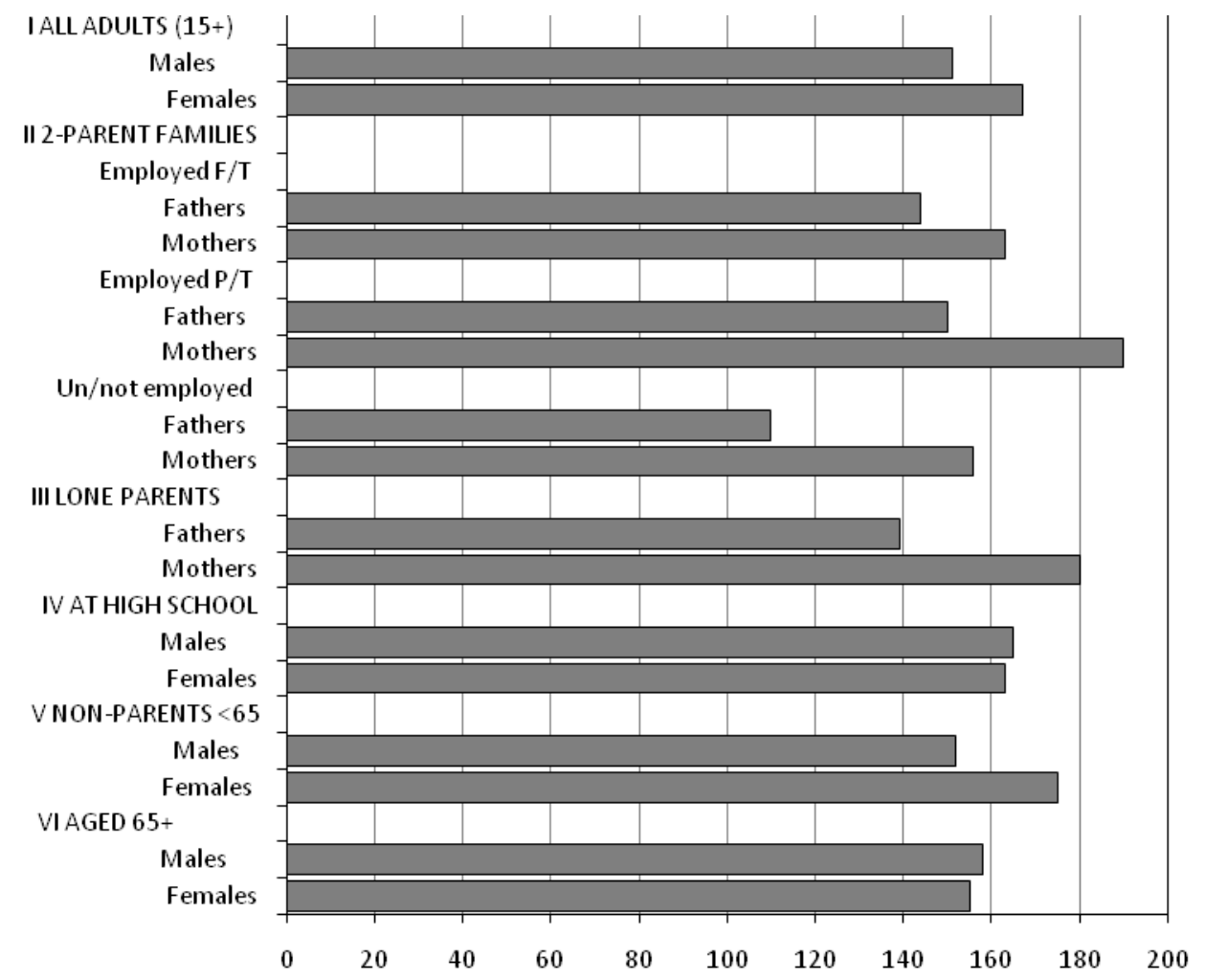

Group average participation: times per year

Source: See Table 1, item 8. Secondary analysis undertaken at UTS: data file supplied by SCORS. NB: Groups not exactly comparable to those in Figure 1.

Figure 4. Trends in time use by gender, Australian adults (15+), 1974-2006 


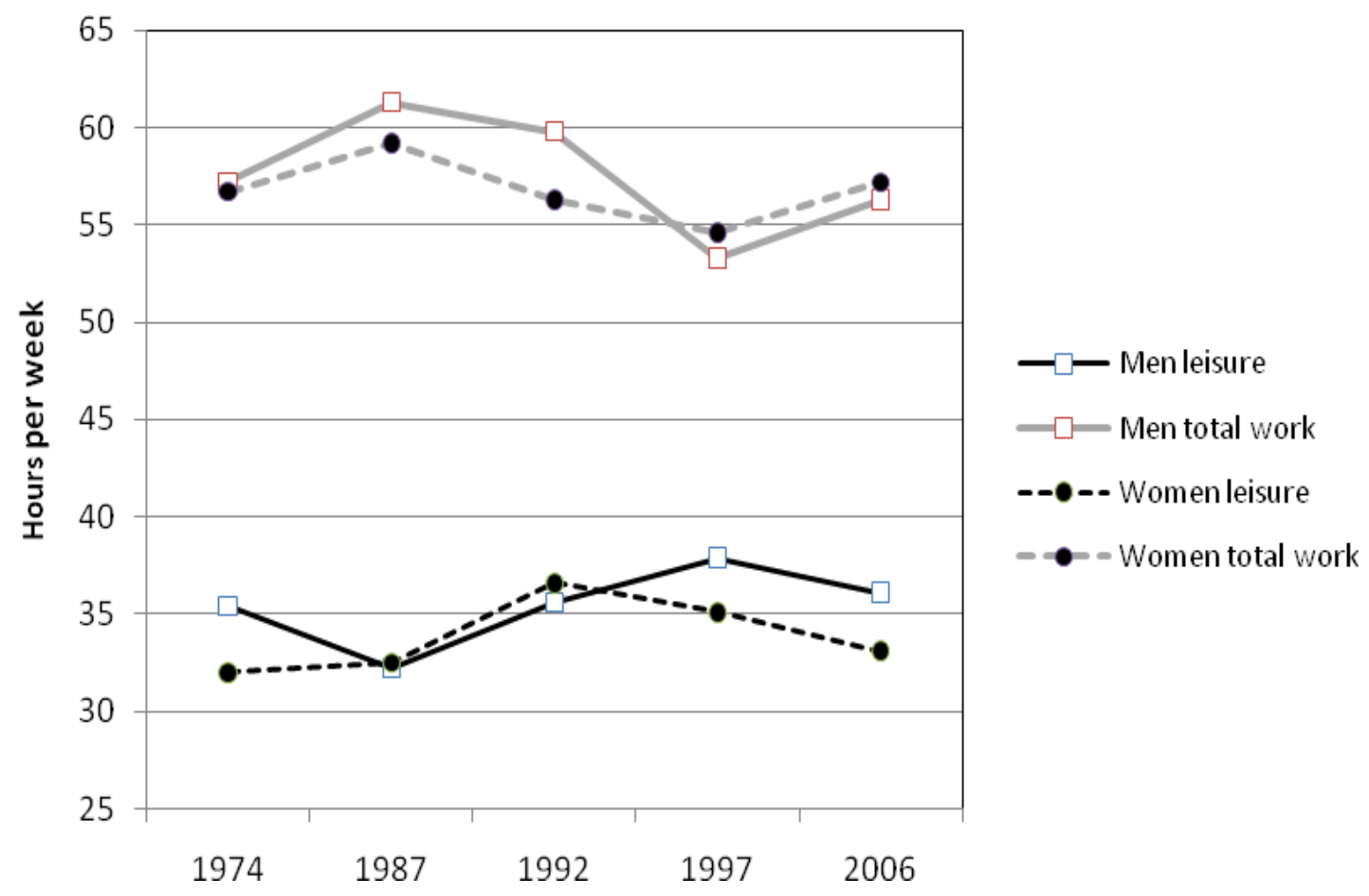

Data sources: 1974-92: Bittman (1998); 1997, 2006: ?? no ABS entries in refsABS see Table 1 item 7. 
Figure 5. Leisure-time use, Australian males (15+), 1997-2006

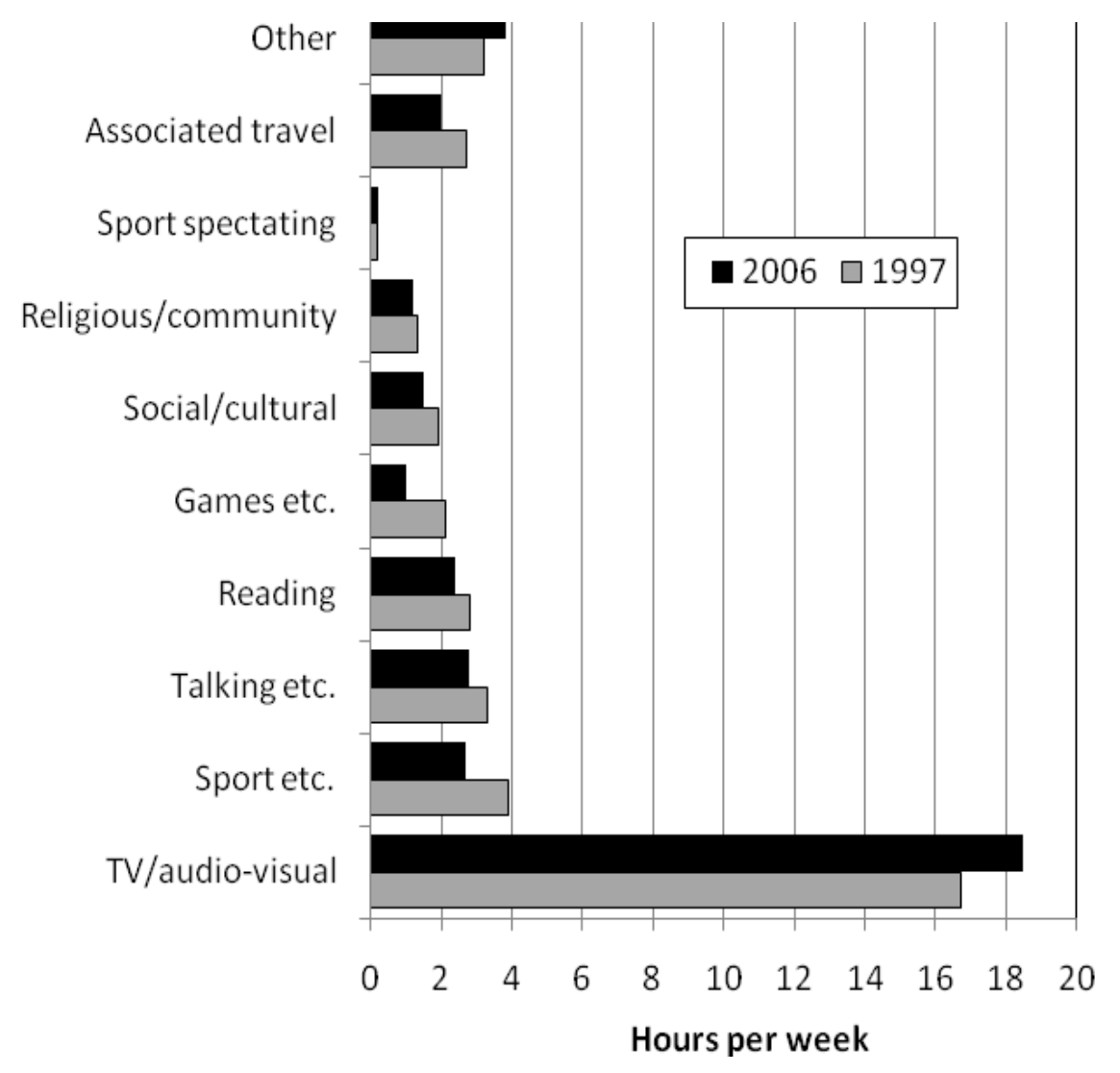


Figure 6. Life time activity patterns, male example, Australia

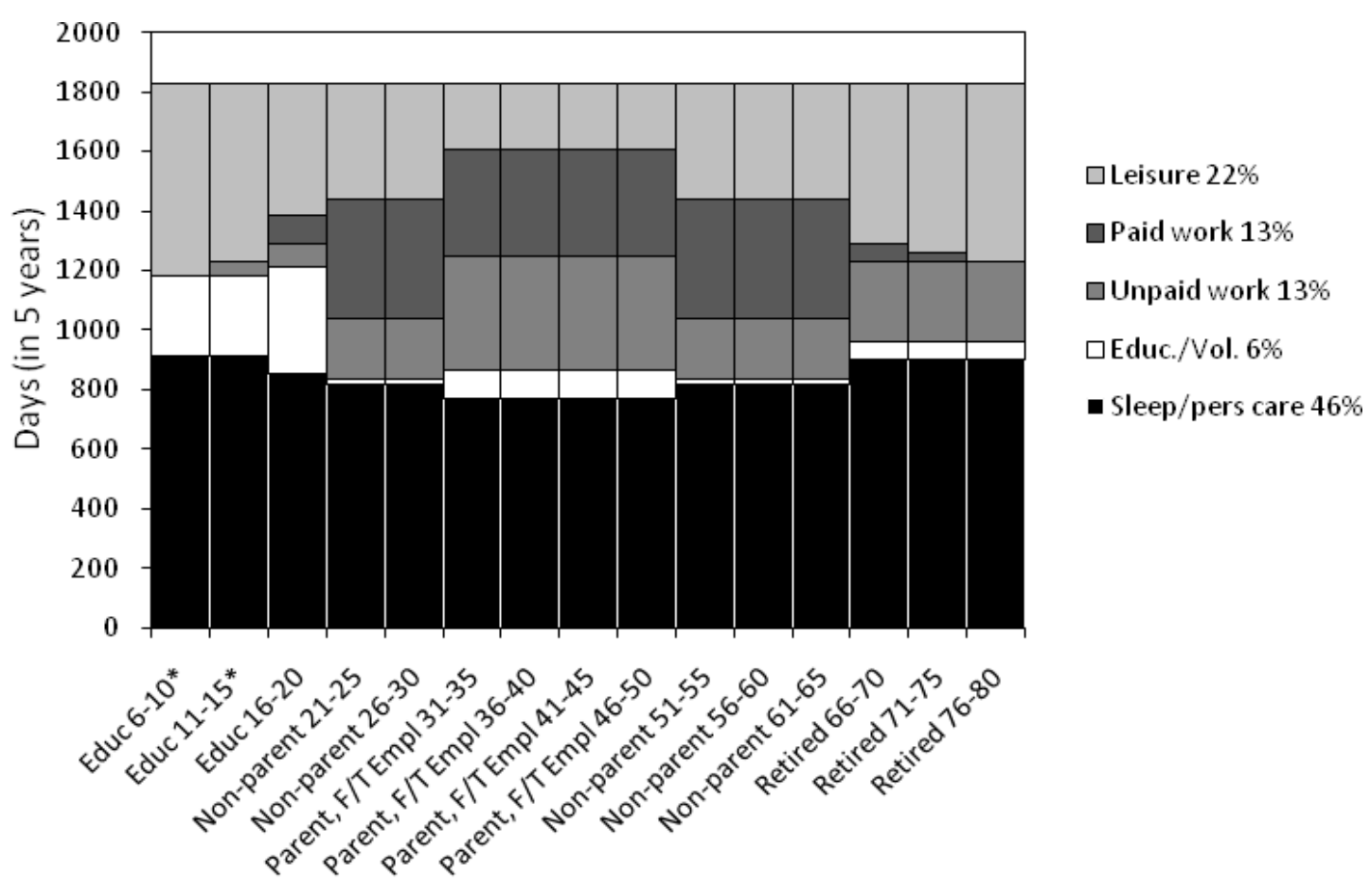

Life-cycle stage

Source: based on ABS data, Table 1, item 7: 2006 ?? No ABS 2006 entry?time-use patterns for each group.

* 6-15 activity pattern author’s estimate 
Figure 7. Life time activity patterns, female example, Australia

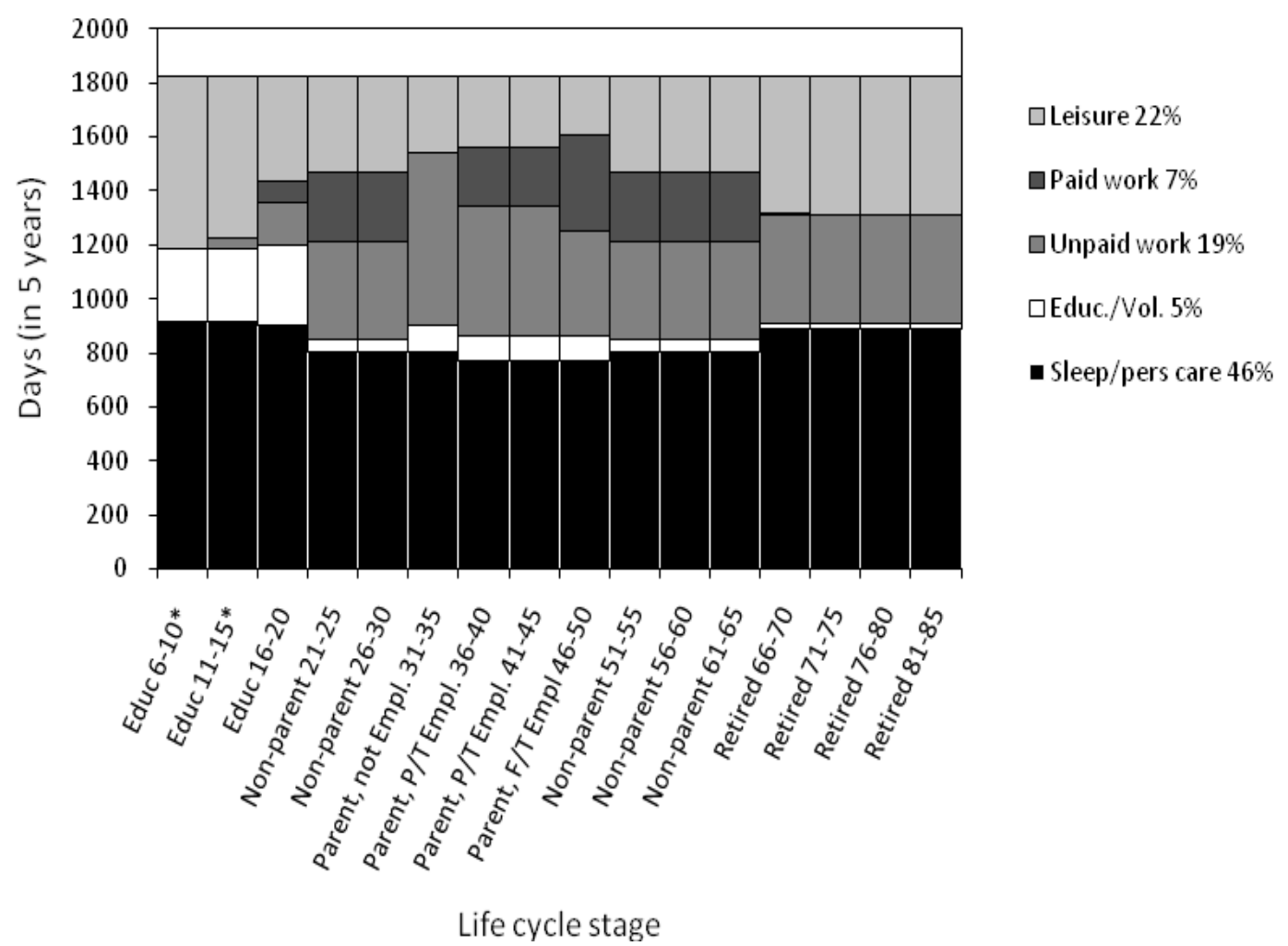

Source: based on ABS data, Table 1, item 7, 2006 time-use patterns for each group.

* 6-15 activity pattern author's estimate

\footnotetext{
${ }^{\text {i }}$ The results of Bittman's earliest analysis were presented in Bittman (1991a and b). In the latter, he concluded that 'Women have gone from a situation of near leisure time parity with men in 1974, to one of disadvantage by 1987' (Bittman, 1991b: 32). In comments on the utilization of time-use survey data for analysis of leisure and gender, Betsy Wearing observed that such findings would 'provide fuel for feminist analysis of gendered inequality in access to "free time", (Wearing, 1998: 17). It should be noted, however, that in order to achieve comparison between Australian and European data, the data Bittman presented related only to people aged 20-59; thus excluding 32\% of women aged 15 and over. In his 1998 paper, which included data from the 1992 ABS survey, he included all adults aged 15 and over, which gave a different picture. It has not been possible to pursue the 20-59 age cohort for the 1992, 1997 and 2006 ABS surveys from published sources.
} 